Received: 05.05.2016.

UDK: [331.54:17.035.1]-057.87

Original scientific work

\title{
FUTURE PROFESSION CHOICE AND ALTRUISM
}

\author{
Srbislava Pavlov \\ The Preschool Teachers Training College in Kikinda, \\ Svetosavska 57, Kikinda, The Republic of Serbia \\ pavlovs@vaspitacka.edu.rs \\ Zagorka Markov \\ The Preschool Teachers Training College in Kikinda, \\ Svetosavska 57, Kikinda, The Republic of Serbia \\ zagorka.markov@gmail.com
}

\begin{abstract}
The paper aims to determine whether there exists a connection between the dimension of altruism and the choice of future profession (either "helping" or "nonhelping") on the sample of 285 respondents, pupils from secondary vocational school "Miloš Crnjanski" from Kikinda, and Preschool Teachers' Training College in Kikinda. The instrumend used in this research is NSA 2000 measurement scale. Factor analysis was used to extract two factors in which particles had been polarized that can be used to define the dimension of altruism. The first extracted factor was defined as hypersensitivity towards others. The other extracted factor indicates insensitivity towards others and a certain level of selfishness towards the needs of the people around us. The findings obtained by variance analysis show that there is a significant statistical difference in the dimension of altruism in favour of the respondents who chose teaching or nursing as their future profession.
\end{abstract}

Keywords: altruism, helping and non-helping professions, students and pupils. 


\section{INTRODUCTION}

In a time of an economic crisis we can see a decline in quality of life and social values, which, from a humanistic perspective, changes human nature considerably. Therefore, Rousseau's belief that humans are good by nature but rendered corrupt by the negative impact of social institutions in the process of socialization is applicable today.

According to Trebješanin, prosocial behaviour means positive and acceptable actions towards other people. Altruistic behaviour can be expressed through care for other people and actions which contribute to their welfare. Thus, it is regarded as one of the most significant factors in upbringing and education for the survival and development of an individual, as well as for the functioning and development of a society in general. Although much research has been done on altruism, the meaning of this concept is still a source of disagreement. However, the majority of definitions share the idea that an altruistic action is performed consciously and intentionally for the benefit of another (Joksimović, 1999, p. 605). Altruism is normally defined as love for other people and readiness to help others, whereas empathy is defined as a capability to identify with or understand the needs of other people. Both altruism and empathy very often involve taking the other person's perspective, which can make the emphatic altruist lose distance and identify with the other person to the point of being unable to help. Even the other person's independence may get in the way as it can remove the need for action. Empathy means understanding of the other person's position, opinion, emotional state and action.

According to some authors there is pathological altruism which is manifested as excessive self-sacrifice and an attempt to reduce one's own pain by helping others, which is, for example, characteristic of domestic violence victims. Bachner-Melmane describes it as "lack of internal compass for what is useful to an individual" so other people get priority over individual needs (Bramstedt, 2012). Joksimović (1999) shares this view but she also observes that some authors stress the necessity of altruistic behaviour for the benefit of others without considering the consequences for the benefactor. The altruistic extreme end of the continuum is occupied by behaviours which are entirely beneficial for the other person, even at personal cost. The other, egoistic end of the continuum is occupied by behaviours contributing to personal advantage, even at the cost of the other person. Altruism is manifested through giving and sharing of material goods, helping with work, rescuing from danger, offering consolation and other kinds of socio-psychological support, therefore Suzić (2014) describes altruism and empathy as emotional competences in the context of lifelong learning.

Previous research has confirmed the connection between altruism and helping professions (Dimitrijević, Hanak, Milojević, 2011) among which education and medical professions have also been considered by some other authors (Ricijaš, Hujić, Branica, 2006). For instance, they examined the satisfaction of students, future helpers and the self-assessment of their competencies. There has also been research into satisfaction of helping professionals working in health and prison facilities.

This research aims to establish whether the choice of career, either helping or nonhelping, is related to the respondents' altruism and whether the respondents as future 
educators, despite the complexity of their profession, inadequate social recognition and income, consider altruistic and compassionate behavior to be essential when it comes to work with pre-school children and the sick.

\section{RESEARCH INTO ALTRUISM AND THE FACTORS INFLUENCING IT}

Altruism as prosocial behavior is a kind of behavior that promotes the welfare of others without expecting anything in return, which is the opposite of aggressive behavior (Beck, 2006). Sadžakov, in his study, examines the fine line between egoism and altruism in the context of ethics and seeks to link the two phenomena with the notions of moral duty, modern identity and the structure of the practical world (Sadžakov, 2014, p. 407).

Multiple studies have shown that praise as a form of social motivation is more closely connected with prosocial actions than material rewards. It has been established that material rewards in certain situations can reduce the tendency among children to offer help, most likely because such incentives decrease intrinsic motivation for prosocial behaviour (Fabes, Fultz, Eisenberg, May-Plumlee, Christopher, 1989).

A study based on a sample of 116 preschool children found that there is a strong correlation between social cognitive abilities and prosocial behavior (Yagmurlu, 2014).

In his study, Post (2005) observes the relationship between altruism, emotions and behavior on one side and wellbeing, health and longevity on the other side. Batson and Powell (Batson \& Powell, 2003: 463) differentiate between prosocial behavior and altruism. Prosocial behavior encompasses a wide range of actions directed at others, such as help, consolation and cooperation with one or more individuals. Altruism is a motivational state with the aim of increasing the other person's welfare, as opposed to egoism which is a motivational state with the aim of increasing personal wellbeing. Cialdini and associates conducted two experiments designed to investigate empathy for patients and victims. Participants expressed not only increased empathic concern, but also increased personal sadness (Cialdini and associates, 1987). Many authors have investigated altruistic behaviour from different aspects. Some investigated the relationship between empathy and altruism (Eisenberg, Miller, 1987), whereas Kruger (2003) investigated the altruistic behavior of over 600 participants towards their relatives. Children between the ages of 14 and 18 help each other to achieve their age appropriate goals, without being positively reinforced by adults. These findings show that humans have a natural predisposition to develop altruistic behaviour. Socialization may encourage such behaviors, although altruistic behaviour may be displayed even before the child has been fully socialized (Warneken, Tomasello, 2009). Changes in prosocial behaviour are not necessarily related to age. Due to the fact that the quality of such behaviour is subject to change, one should expect changes based on cognitive development. Gradually, prosocial behaviour becomes more adequate with respect to the situation and the needs of the person at which it is directed (Krebs, 1970).

Social competence is a very important concept for understanding prosocial behaviour. Consequently, it has generated considerable interest. In order to predict 
other person's behavior it is necessary to understand the underlying motivation. Communication is paramount in education. Pupils communicate with each other and their teachers and often conflicts arise. For this reason, communication skills are of great importance for developing prosocial behavior, as without communication it cannot be learned. Often, education is identified with socialization and there is a number of studies examining the role of school in the process of socialization (Ivanović, 2010, p. 292). Research findings (Grgić, Babić Čikeš, Ručević, 2014) show that the potential for predicting prosocial behavior on the basis of emotional intelligence parameters represents a statistically major positive predictor with regard to prosocial behavior of adolescents. The research included a sample of 187 male and 120 female respondents aged between 12 and 15 years. Findings reveal that psychology students (future helpers) are more superior with regard to showing empathy as well. Psychology students have greater capacity to take other people's perspective and imagine and feel other people's emotions; they have a greater capacity for the tolerance of great temporary closeness with another person without losing insight into their own internal states (Dimitrijević, Hanak, Milojević, 2011, p. 108). Findings of one study indicate that prosocial motivation plays a significant role in both a decision to enroll in a nursing school and later in future job commitment (Nesje, 2015). Research findings (Raboteg-Šarić, 1997, p. 493) show that prosocial behaviour can be best predicted on the basis of emotional empathy, whereas moral judgment is not related to prosocial behavior. Considerable interaction was found between empathy and the maturity of moral judgment. The connection between empathy and prosocial behavior is stronger at higher stages of moral judgment. Major differences in prosocial behavior of respondents of different sex were found. Additional data analyses showed that more frequent prosocial behavior of girls can be assigned to their more pronounced tendency towards empathy. Numerous research findings show a strong presence of altruism and empathy in medical professions and greater empathy in female respondents (Tešanović, Đurić, Popović, 2011, p. 12). Research conducted by Slađana Luković and Svetlana Čizmić confirms that lifestyle preferences are based on one's orientation towards popularity, altruism and promethean activism, whereas in the field of professional interests these are culture and humanistic and health work. The sample included 229 fifteen-year-olds. Respondents who were not oriented towards fulfilling their own goals were more interested in humanistic health work (Luković, Čizmić, 2012, p. 95). A large number of professions involve providing help to others. Physicians, nurses, psychologists, psychotherapists and social workers should be encouraged to promote and improve thier personal welfare, as well as the welfare of their clients. These professions have been described as helping professions, teachers and educators are included, as well (Dimitrijević, Hanak, Milojević, 2011, p. 97). Milenković and Šakotić-Kurbalija (1997) research findings indicate that psychotherapists of different theoretical orientations perceive that empathy is the dominant motivator of altruistic behaviour. 


\section{THE AIM OF RESEARCH}

We aim to identify differences and similarities in the level of altruism in respondents who have chosen a helping profession and in those who have chosen a non-helping profession.

\section{RESEARCH METHODS}

\section{Respondents and the procedure}

The sample in this study included third and fourth grade pupils from the vocational secondary school "Miloš Crnjanski" in Kikinda who specialize in both medical and non-medical fields, and students at the Preschool Teachers Training College in Kikinda, the Republic of Serbia. The sample consists of the total of 138 secondary school pupils (48.4\%) and 147 students (51. 6\%). The chi-square test value of $\chi^{2}=0,284$ is above the significance level $p=0,594$, which indicates that the sample is balanced as regards the number of participants from the two schools which differ in terms of type and level of education. This study involved $76(26,67 \%)$ third grade pupils, $62(21,75 \%)$ fourth grade pupils, $66(23,16 \%)$ first year students, $50(17,54 \%)$ second year students and $31(10,88 \%)$ third year students. The chi-square test value of $\chi^{2}=20,912$ is below the significance level $p=0,001$ which indicates that the sample was not balanced in terms of grades or the years of study. The sample included 220 (77,19\%) female respondents and $65(22,81 \%)$ male respondents. The research was conducted during teaching sessions in November and December 2015 with the participats' verbal consent.

\section{Instruments}

The instrument used in this research was NSA 2000 measurement scale (Mladenović, Kosanović, 2000) whose reliability has been established by applying Cronbach alpha test which returned the value of 0,786 for both groups. Information about the research topic i.e. the conection between career choice and altruism and our expectations from respondents are set out in the introduction, whereas the second part consists of fourty items in the form of a five point Likert scale.

The responses were scored according to the following scale: $1=$ strongly agree, $2=$ mostly agree, 3 = undecided, $4=$ mostly disagree, 5 = strongly disagree. The respondents' altruistic behaviour was measured via this scale. 


\section{RESULTS AND DISCUSSION}

The main components of the statements in the NSA 2000 scale have been analyzed. By applying the scree criterion, two main components have been retained in the analysis which jointly explain $53,51 \%$ of the total variables.

The retained main components were rotated using oblimin rotation. These results are presented in Table 1. We used factor analysis in order to establish interdependence between our variables and to interpret them using a smaller number of underlying factors. $\mathrm{KMO}$ measure of sampling adequacy shows that the correlation matrix is appropriate for factor analysis and it measures $\mathrm{KMO}=0,889$, whereas Bertlett's p-value of 0,000 is significant and it confirms that the use of factor analysis has been justified. analysis.

The precent of variance of 53,81\% has been explained by Principal Axis Factoring

The scree plot displays a sharp break between the second and the third component, therefore we singled out the two factors (Graph 1).

Graph 1. Factor number

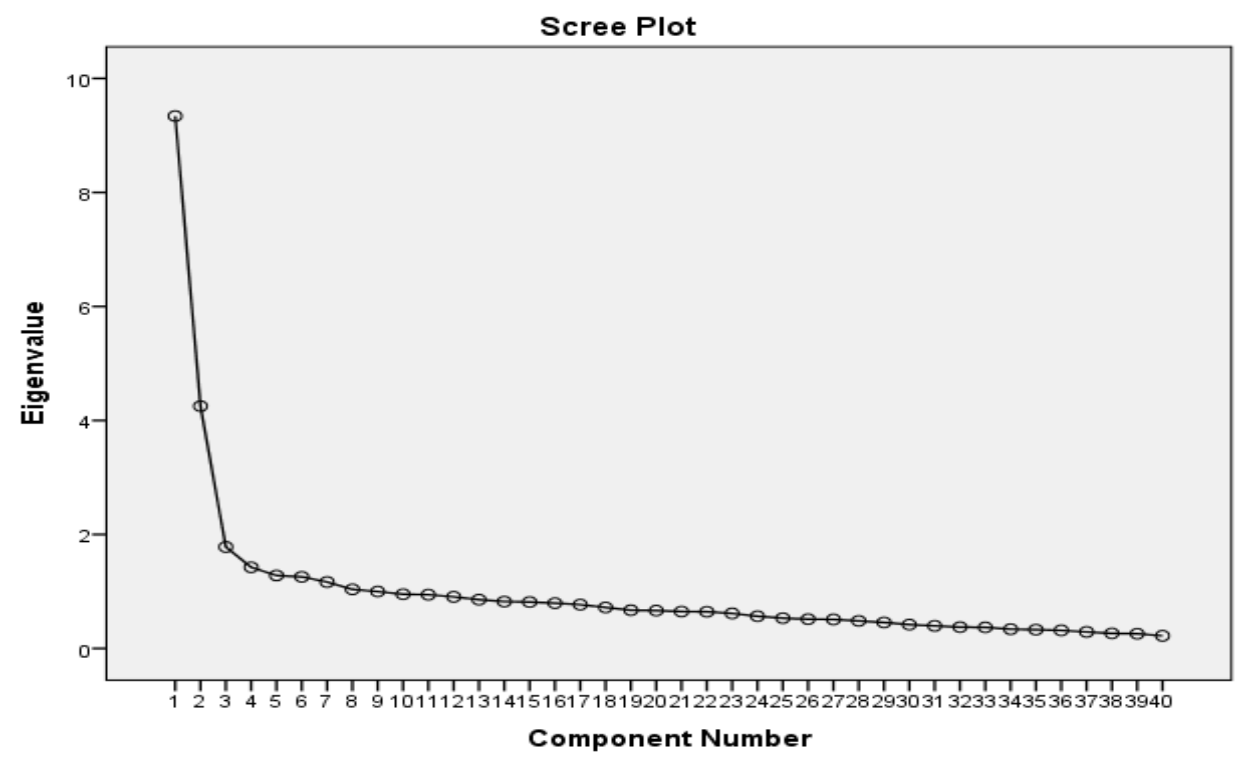

Components - factors

After oblimin rotation, the latent structure of the first factor reveals social support and hypersensitivity to others (Table 1). This finding shows that both the pupils and students highly value helping others. This factor is composed of thirteen items: The Red Cross is an organization whose existence is purposeful and justified; I would offer to help if someone fell or passed out in the street; We should do good to other people without expecting anything in return; I like to take part in activities aimed at helping others; 
It always angers me to see the powerful ignoring the powerless; The most important thing children should learn at school is being ready to help others; I help both those who expect it and those who do not; I feel sorry for people in need; Kind words are also helpful when times are tough; I enjoy giving pleasure to others; People should take part in voluntary blood donation campaigns; By helping others, one can make new friends; Even in the most difficult times, people have the strength to be kind and generous.

Table 1. Primary factors for the assessment of altruism in pupils and students

\begin{tabular}{|c|c|c|}
\hline \multirow[t]{2}{*}{ Factor } & \multicolumn{2}{|c|}{ Components after rotation } \\
\hline & 1 & 2 \\
\hline \multirow[t]{13}{*}{ Social support/hypersensitivity to others } & 0,697 & \\
\hline & 0,682 & \\
\hline & 0,681 & \\
\hline & 0,648 & \\
\hline & 0,643 & \\
\hline & 0,640 & \\
\hline & 0,629 & \\
\hline & 0,628 & \\
\hline & 0,621 & \\
\hline & 0,620 & \\
\hline & 0,615 & \\
\hline & 0,610 & \\
\hline & 0,609 & \\
\hline \multirow[t]{14}{*}{ Social indifference and selfishness } & & 0,629 \\
\hline & & 0,600 \\
\hline & & 0,580 \\
\hline & & 0,556 \\
\hline & & 0,538 \\
\hline & & 0,515 \\
\hline & & 0,489 \\
\hline & & 0,476 \\
\hline & & 0,470 \\
\hline & & 0,462 \\
\hline & & 0,461 \\
\hline & & 0,438 \\
\hline & & 0,411 \\
\hline & & 0,367 \\
\hline
\end{tabular}

Extraction method: Analysis of principled components. Rotation method. Oblimin with Kaiser normalization. 
It is reassuring that social support or hypersensitivity towards others stands out as the dominant factor in the pupils' and students' order of priority. The analysis of items which correlate with these factors reveals the type of altruism which is dominated by the willingness to care for others and the wish to help in difficult situations. Social indifference and selfishness stands out as the second factor (Table 1).

This factor is composed of thirteen items: People usually help each other for personal gain; The majority of people I know are selfish; There are a lot of those who tend to take as much as possible and give as little as possible; There are a lot of people who don't deserve any help; The more developed the world becomes, the less help people provide; Everyone should live by the proverb Distrust is the mother of safety; Help yourself before you help the others; I am fed up with stories about other people's problems; The more rich someone is, the less ready they are to help others; Sometimes I help other people, but they don't appreciate it; It's better to save your hide than risk your neck for someone; Most people tend to take advantage of others; Helping others simply doesn't pay off; I think people today don't deserve any help.

A comparison of the two extracted factors reveals that they are polar opposites. Namely, the first factor consists of items indicating altruism in the respondents, whereas the other factor comprises of statements expressing disregard of others and selfishness. The division into helping and non-helping professions is based on the specific field of work they fall into.

Educational profiles nurse technician and pharmacy technician fall into the field of healthcare and social care, whereas preschool teachers are being educated in the area of social sciences. On the basis of the field of work, we have classified these as helping professions. Educational profile architectural technician falls into geodesy and construction, environmental protection technician falls into the field of chemistry, nonmetals, whereas food processing technician and agricultural biotechnology technician fall into the field of agriculture and food processing, respectively. We have classified these profiles as non-helping professions. The chi-square test value of $\chi^{2}=40,172$ is below the significance level of $p=0,001$, which indicates that the sample is not balanced.

By applying a discriminant analysis of the two isolated factors, namely, the component of altruism (hypersensitivity to others) and social indiferrence or selfishness, a statistically significant function has been identified which separates the two groups according to the level of altruism expressed (helping and non-helping profession).

Table 2. Results of discriminant analysis

\begin{tabular}{|l|l|l|l|l|}
\hline function & Eigenvalue & Percent variance & $\begin{array}{l}\text { Cumulative } \\
\text { percentage }\end{array}$ & Canonical correlation \\
\hline 1. & 0.32 & 31.00 & 100.0 & .171 \\
\hline 2. & 0.67 & 68.2 & 68.2 & .247 \\
\hline
\end{tabular}


Discriminant analysis results are presented in Table 4. In this analysis the bipolar discriminative dimension has been isolated, whose positive pole defines hypersensitivity towards other people, whereas the negative pole of this dimension has been rendered through the component social indifference/ selfishness (Table 2).

Table 3. Discriminant function values and their significance

\begin{tabular}{|l|l|l|l|l|}
\hline function & Wilk's lambda & $\mathrm{X}$ & $\mathrm{df}$ & $\mathrm{p}$ \\
\hline 1. & .960 & 9.984 & 5 & .071 \\
\hline 2. & .910 & 31.414 & 12 & .002 \\
\hline
\end{tabular}

Differences between the respondents belonging to helping and non-helping professions are presented in Table 3. Following the results from this table, we can see that altruism is more pronounced among the respondents who chose a helping profession as their future career, namely, medical or educational. Of all the indicators applied, those which stood out at the first discriminant function as the dimension of altruism - hypersensitivity towards others, have a significantly greater value than the other ones (Table 4).

Table 4. Discriminant function matrix structure

\begin{tabular}{|l|l|l|}
\hline & $\begin{array}{l}\text { Variable - components } \\
\text { of altruism }\end{array}$ & Function 1 \\
\hline 1. & Hypersensitivity to others & .435 \\
\hline 2. & Social indifference/selfishness & -.439 \\
\hline
\end{tabular}

Data on group centroids presented in Table 5 indicate that altruism is more prominent among the respondents who chose a helping profession.

Table 5. Group centroids

\begin{tabular}{|l|l|l|}
\hline & Profession choice & Function 1 \\
\hline 1. & helping & .277 \\
\hline 2. & Non-helping & .032 \\
\hline
\end{tabular}

We have used one-way analysis of variance ANOVA to investigate the impact of career choice, helping or non-helping, on altruism. Results are presented in Table 6. 
Table 6. Career choice and altruism

\begin{tabular}{|c|c|c|c|c|c|c|}
\hline Variables & Career choice & $N$ & $M$ & $S D$ & $F$ & $\begin{array}{c}\text { Significance } \\
p\end{array}$ \\
\hline \multirow{3}{*}{$\begin{array}{l}\text { I prefer helping others } \\
\text { to receiving help from } \\
\text { others }\end{array}$} & helping professions & 196 & 2,13 & 0,94 & & \\
\hline & $\begin{array}{l}\text { Non-helping } \\
\text { professions }\end{array}$ & 89 & 2,53 & 1,21 & & \\
\hline & Total & 285 & 2,25 & 1,04 & 9,20 & 0,003 \\
\hline \multirow{3}{*}{$\begin{array}{l}\text { Kind words are also } \\
\text { helpful when times are } \\
\text { tough. }\end{array}$} & helping professions & 196 & 1,70 & 1,07 & & \\
\hline & $\begin{array}{l}\text { Non-helping } \\
\text { professions }\end{array}$ & 89 & 1,80 & 1,07 & & \\
\hline & Total & 285 & 1,73 & 1,07 & 0,47 & 0,495 \\
\hline \multirow{3}{*}{$\begin{array}{l}\text { Even in the most difficult } \\
\text { times, people have the } \\
\text { strength to be kind and } \\
\text { generous. }\end{array}$} & helping professions & 196 & 1,94 & 1,08 & & \\
\hline & $\begin{array}{l}\text { Non-helping } \\
\text { professions }\end{array}$ & 89 & 2,43 & 1,24 & & \\
\hline & Total & 285 & 2,09 & 1,16 & 11,77 & 0,001 \\
\hline \multirow{3}{*}{$\begin{array}{l}\text { It is honorable and } \\
\text { respectable to make } \\
\text { sacrifices for others. }\end{array}$} & helping professions & 196 & 1,97 & 1,02 & & \\
\hline & $\begin{array}{l}\text { Non-helping } \\
\text { professions }\end{array}$ & 89 & 2,47 & 1,12 & & \\
\hline & Total & 285 & 2,13 & 1,07 & 14,02 & 0,000 \\
\hline \multirow{3}{*}{$\begin{array}{l}\text { It always angers me to see } \\
\text { the powerful ignoring the } \\
\text { powerless. }\end{array}$} & helping professions & 196 & 1,88 & 1,17 & & \\
\hline & $\begin{array}{l}\text { Non-helping } \\
\text { professions }\end{array}$ & 89 & 2,42 & 1,45 & & \\
\hline & Total & 285 & 2,05 & 1,29 & 11,08 & 0,001 \\
\hline \multirow{3}{*}{$\begin{array}{l}\text { The most important thing } \\
\text { children should learn at } \\
\text { school is being ready to } \\
\text { help others. }\end{array}$} & helping professions & 196 & 1,98 & 1,00 & & \\
\hline & $\begin{array}{l}\text { Non-helping } \\
\text { professions }\end{array}$ & 89 & 2,53 & 1,31 & & \\
\hline & Total & 285 & 2,15 & 1,13 & 15,06 & 0,000 \\
\hline \multirow{3}{*}{$\begin{array}{l}\text { People should make an } \\
\text { effort and sacrifices to } \\
\text { help someone. }\end{array}$} & helping professions & 196 & 1,07 & 2,47 & & \\
\hline & $\begin{array}{l}\text { Non-helping } \\
\text { professions }\end{array}$ & 89 & 1,17 & 2,56 & & \\
\hline & Total & 285 & 1,10 & 2,50 & 0,43 & 0,513 \\
\hline
\end{tabular}




\begin{tabular}{|c|c|c|c|c|c|c|}
\hline \multirow{3}{*}{$\begin{array}{l}\text { I enjoy giving pleasure to } \\
\text { others. }\end{array}$} & helping professions & 196 & 2,05 & 0,99 & & \\
\hline & $\begin{array}{l}\text { Non-helping } \\
\text { professions }\end{array}$ & 89 & 2,48 & 1,18 & & \\
\hline & Total & 285 & 2,19 & 1,08 & 10,38 & 1,001 \\
\hline \multirow{3}{*}{$\begin{array}{l}\text { I believe in the saying: } \\
\text { When you do good, you } \\
\text { can expect good“. }\end{array}$} & helping professions & 196 & 1,98 & 1,18 & & \\
\hline & $\begin{array}{l}\text { Non-helping } \\
\text { professions }\end{array}$ & 89 & 2,30 & 1,38 & & \\
\hline & Total & 285 & 2,08 & 1,26 & 3,99 & 0,047 \\
\hline \multirow{3}{*}{$\begin{array}{l}\text { I believe that people } \\
\text { should charge for their } \\
\text { favours. }\end{array}$} & helping professions & 196 & 4,18 & 1,08 & & \\
\hline & $\begin{array}{l}\text { Non-helping } \\
\text { professions }\end{array}$ & 89 & 3,64 & 1,48 & & \\
\hline & Total & 285 & 4,01 & 1,24 & 12,12 & 0,001 \\
\hline \multirow{3}{*}{$\begin{array}{l}\text { People are good and they } \\
\text { should be helped. }\end{array}$} & helping professions & 196 & 2,71 & 0,95 & & \\
\hline & $\begin{array}{l}\text { Non-helping } \\
\text { professions }\end{array}$ & 89 & 2,81 & 1,21 & & \\
\hline & Total & 285 & 2,74 & 1,04 & 0,50 & 0,478 \\
\hline \multirow{3}{*}{$\begin{array}{l}\text { By helping others, one can } \\
\text { make friends. }\end{array}$} & helping professions & 196 & 2,01 & 0,95 & & \\
\hline & $\begin{array}{l}\text { Non-helping } \\
\text { professions }\end{array}$ & 89 & 2,26 & 1,21 & & \\
\hline & Total & 285 & 2,09 & 1,04 & 3,20 & 0,074 \\
\hline \multirow{3}{*}{$\begin{array}{l}\text { I would volunteer for } \\
\text { charitable organizations. }\end{array}$} & helping professions & 196 & 1,93 & 1,18 & & \\
\hline & $\begin{array}{l}\text { Non-helping } \\
\text { professions }\end{array}$ & 89 & 2,24 & 1,25 & & \\
\hline & Total & 285 & 2,03 & 1,21 & 4,13 & 0,043 \\
\hline \multirow{3}{*}{$\begin{array}{l}\text { What refugees' } \\
\text { commissioner does is } \\
\text { humane and noble. }\end{array}$} & helping professions & 196 & 2,14 & 1,01 & & \\
\hline & $\begin{array}{l}\text { Non-helping } \\
\text { professions }\end{array}$ & 89 & 2,29 & 1,02 & & \\
\hline & Total & 285 & 2,19 & 1,01 & 1,42 & 0,234 \\
\hline \multirow{3}{*}{$\begin{array}{l}\text { People should do good } \\
\text { without expecting } \\
\text { anything in return. }\end{array}$} & helping professions & 196 & 1,82 & 0,98 & & \\
\hline & $\begin{array}{l}\text { Non-helping } \\
\text { professions }\end{array}$ & 89 & 2,16 & 1,16 & & \\
\hline & Total & 285 & 1,92 & 1,05 & 6,60 & 0,011 \\
\hline
\end{tabular}




\begin{tabular}{|c|c|c|c|c|c|c|}
\hline \multirow{3}{*}{$\begin{array}{l}\text { I stick to the rule: Help } \\
\text { people and god will repay } \\
\text { you. }\end{array}$} & helping professions & 196 & 1,84 & 1,09 & & \\
\hline & $\begin{array}{l}\text { Non-helping } \\
\text { professions }\end{array}$ & 89 & 1,90 & 1,30 & & \\
\hline & Total & 285 & 1,86 & 1,16 & 0,15 & 0,701 \\
\hline \multirow{3}{*}{$\begin{array}{l}\text { I believe that people today } \\
\text { don't deserve any help. }\end{array}$} & helping professions & 196 & 4,18 & 1,07 & & \\
\hline & $\begin{array}{l}\text { Non-helping } \\
\text { professions }\end{array}$ & 89 & 3,68 & 1,40 & & \\
\hline & Total & 285 & 4,03 & 1,21 & 10,79 & 0,001 \\
\hline \multirow{3}{*}{$\begin{array}{l}\text { Helping others simply } \\
\text { doesn't pay off. }\end{array}$} & helping professions & 196 & 4,11 & 1,07 & & \\
\hline & $\begin{array}{l}\text { Non-helping } \\
\text { professions }\end{array}$ & 89 & 3,74 & 1,32 & & \\
\hline & Total & 285 & 4,00 & 1,16 & 6,32 & 0,012 \\
\hline \multirow{3}{*}{$\begin{array}{l}\text { The wealthier the people, } \\
\text { the less willing they are } \\
\text { to help. }\end{array}$} & helping professions & 196 & 2,84 & 1,30 & & \\
\hline & $\begin{array}{l}\text { Non-helping } \\
\text { professions }\end{array}$ & 89 & 2,44 & 1,40 & & \\
\hline & Total & 285 & 2,72 & 1,34 & 5,60 & 0,019 \\
\hline \multirow{3}{*}{$\begin{array}{l}\text { An organized and busy } \\
\text { person doesn't have time } \\
\text { for other people. }\end{array}$} & helping professions & 196 & 3,37 & 1,23 & & \\
\hline & $\begin{array}{l}\text { Non-helping } \\
\text { professions }\end{array}$ & 89 & 3,20 & 1,44 & & \\
\hline & Total & 285 & 3,32 & 1,30 & 0,99 & 0,320 \\
\hline \multirow{3}{*}{$\begin{array}{l}\text { Help yourself before you } \\
\text { help others. }\end{array}$} & helping professions & 196 & 3,11 & 1,20 & & \\
\hline & $\begin{array}{l}\text { Non-helping } \\
\text { professions }\end{array}$ & 89 & 2,71 & 1,39 & & \\
\hline & Total & 285 & 2,99 & 1,27 & 6,29 & 0,013 \\
\hline \multirow{3}{*}{$\begin{array}{l}\text { People should take part in } \\
\text { voluntary blood donation } \\
\text { campaigns }\end{array}$} & helping professions & 196 & 1,68 & 1,05 & & \\
\hline & $\begin{array}{l}\text { Non-helping } \\
\text { professions }\end{array}$ & 89 & 1,77 & 1,14 & & \\
\hline & Total & 285 & 1,71 & 1,08 & 0,49 & 0,483 \\
\hline \multirow{3}{*}{$\begin{array}{l}\text { There are a lot of people } \\
\text { who don't deserve help. }\end{array}$} & helping professions & 196 & 3,17 & 1,27 & & \\
\hline & $\begin{array}{l}\text { Non-helping } \\
\text { professions }\end{array}$ & 89 & 2,93 & 1,46 & & \\
\hline & Total & 285 & 3,10 & 1,33 & 2,00 & 0,158 \\
\hline
\end{tabular}




\begin{tabular}{|c|c|c|c|c|c|c|}
\hline \multirow{3}{*}{$\begin{array}{l}\text { I like to be involved in } \\
\text { campaigns aimed at } \\
\text { helping others. }\end{array}$} & helping professions & 196 & 1,97 & 1,08 & & \\
\hline & $\begin{array}{l}\text { Non-helping } \\
\text { professions }\end{array}$ & 89 & 2,33 & 1,27 & & \\
\hline & Total & 285 & 2,08 & 1,15 & 6,11 & 0,014 \\
\hline \multirow{3}{*}{$\begin{array}{l}\text { The Red Cross is an } \\
\text { organization whose } \\
\text { existence is purposeful } \\
\text { and justified. }\end{array}$} & helping professions & 196 & 1,61 & 1,09 & & \\
\hline & $\begin{array}{l}\text { Non-helping } \\
\text { professions }\end{array}$ & 89 & 1,95 & 1,33 & & \\
\hline & Total & 285 & 1,72 & 1,18 & 5,40 & 0,021 \\
\hline \multirow{3}{*}{$\begin{array}{l}\text { People help others mostly } \\
\text { for personal gain. }\end{array}$} & helping professions & 196 & 2,99 & 1,18 & & \\
\hline & $\begin{array}{l}\text { Non-helping } \\
\text { professions }\end{array}$ & 89 & 2,43 & 1,16 & & \\
\hline & Total & 285 & 2,81 & 1,20 & 14,15 & 0,000 \\
\hline \multirow{3}{*}{$\begin{array}{l}\text { I feel sorry for people in } \\
\text { need. }\end{array}$} & helping professions & 196 & 1,62 & 0,99 & & \\
\hline & $\begin{array}{l}\text { Non-helping } \\
\text { professions }\end{array}$ & 89 & 1,76 & 1,12 & & \\
\hline & Total & 285 & 1,66 & 1,03 & 1,23 & 0,27 \\
\hline \multirow{3}{*}{$\begin{array}{l}\text { I help both those who } \\
\text { expect it and those who } \\
\text { do not. }\end{array}$} & helping professions & 196 & 1,83 & 0,85 & & \\
\hline & $\begin{array}{l}\text { Non-helping } \\
\text { professions }\end{array}$ & 89 & 2,36 & 1,32 & & \\
\hline & Total & 285 & 2,00 & 1,05 & 16,31 & 0,000 \\
\hline \multirow{3}{*}{$\begin{array}{l}\text { The majority of people I } \\
\text { know are selfish. }\end{array}$} & helping professions & 196 & 2,95 & 1,15 & & \\
\hline & $\begin{array}{l}\text { Non-helping } \\
\text { professions }\end{array}$ & 89 & 2,53 & 1,31 & & \\
\hline & Total & 285 & 2,82 & 1,21 & 7,53 & 0,006 \\
\hline \multirow{3}{*}{$\begin{array}{l}\text { There are a lot of those } \\
\text { who tend to take as much } \\
\text { as possible and give as } \\
\text { little as possible }\end{array}$} & helping professions & 196 & 2,14 & 1,06 & & \\
\hline & $\begin{array}{l}\text { Non-helping } \\
\text { professions }\end{array}$ & 89 & 2,20 & 1,29 & & \\
\hline & Total & 285 & 2,16 & 1,14 & 0,17 & 0,683 \\
\hline
\end{tabular}




\begin{tabular}{|c|c|c|c|c|c|c|}
\hline \multirow{3}{*}{$\begin{array}{l}\text { I am fed up with stories } \\
\text { about other people's } \\
\text { problems. }\end{array}$} & helping professions & 196 & 3,45 & 1,16 & & \\
\hline & $\begin{array}{l}\text { Non-helping } \\
\text { professions }\end{array}$ & 89 & 2,92 & 1,34 & & \\
\hline & Total & 285 & 3,28 & 1,24 & 11,51 & 0,001 \\
\hline \multirow{3}{*}{$\begin{array}{l}\text { A lot of people are willing } \\
\text { to help me because they } \\
\text { know I am not selfish. }\end{array}$} & helping professions & 196 & 2,24 & 1,04 & & \\
\hline & $\begin{array}{l}\text { Non-helping } \\
\text { professions }\end{array}$ & 89 & 2,22 & 1,23 & & \\
\hline & Total & 285 & 2,24 & 1,10 & 0,02 & 0,687 \\
\hline \multirow{3}{*}{$\begin{array}{l}\text { Most people tend to take } \\
\text { advantage of others. }\end{array}$} & helping professions & 196 & 2,46 & 1,77 & & \\
\hline & $\begin{array}{l}\text { Non-helping } \\
\text { professions }\end{array}$ & 89 & 2,19 & 1,30 & & \\
\hline & Total & 285 & 2,37 & 1,64 & 1,63 & 0,202 \\
\hline \multirow{3}{*}{$\begin{array}{l}\text { The more developed the } \\
\text { world becomes, the less } \\
\text { help people provide. }\end{array}$} & helping professions & 196 & 2,53 & 1,19 & & \\
\hline & $\begin{array}{l}\text { Non-helping } \\
\text { professions }\end{array}$ & 89 & 2,72 & 1,26 & & \\
\hline & Total & 285 & 2,59 & 1,21 & 1,48 & 0,224 \\
\hline \multirow{3}{*}{$\begin{array}{l}\text { Sometimes I help other } \\
\text { people, but they do not } \\
\text { appreciate it. }\end{array}$} & helping professions & 196 & 1,77 & 1,01 & & \\
\hline & $\begin{array}{l}\text { Non-helping } \\
\text { professions }\end{array}$ & 89 & 1,85 & 1,11 & & \\
\hline & Total & 285 & 1,80 & 1,04 & 0,34 & 0,558 \\
\hline \multirow{3}{*}{$\begin{array}{l}\text { Most people don't have } \\
\text { the opportunity to help } \\
\text { others. }\end{array}$} & helping professions & 196 & 2,83 & 1,24 & & \\
\hline & $\begin{array}{l}\text { Non-helping } \\
\text { professions }\end{array}$ & 89 & 2,68 & 1,43 & & \\
\hline & Total & 285 & 2,78 & 1,30 & 0,72 & 0,398 \\
\hline \multirow{3}{*}{$\begin{array}{l}\text { Everyone should live by } \\
\text { the proverb: Distrust is } \\
\text { the mother of safety. }\end{array}$} & helping professions & 196 & 2,72 & 1,25 & & \\
\hline & $\begin{array}{l}\text { Non-helping } \\
\text { professions }\end{array}$ & 89 & 2,63 & 1,33 & & \\
\hline & Total & 285 & 2,69 & 1,27 & 0,34 & 0,56 \\
\hline \multirow{3}{*}{$\begin{array}{l}\text { I act in accordance with: } \\
\text { If someone throws a stone } \\
\text { at you, throw a piece of } \\
\text { bread at him. }\end{array}$} & helping professions & 196 & 2,64 & 1,14 & & \\
\hline & $\begin{array}{l}\text { Non-helping } \\
\text { professions }\end{array}$ & 89 & 2,71 & 1,24 & & \\
\hline & Total & 285 & 2,66 & 1,17 & 0,22 & 0,641 \\
\hline
\end{tabular}




\begin{tabular}{|l|l|c|c|c|c|c|}
\hline \multirow{4}{*}{$\begin{array}{l}\text { It's better to save your } \\
\text { hide than risk your neck } \\
\text { for someone. }\end{array}$} & helping professions & 196 & 3,25 & 0,99 & & \\
\cline { 2 - 7 } & $\begin{array}{l}\text { Non-helping } \\
\text { professions }\end{array}$ & 89 & 2,92 & 1,37 & & \\
\cline { 2 - 7 } & Total & 285 & 3,15 & 1,14 & 5,36 & 0,021 \\
\hline \multirow{2}{*}{$\begin{array}{l}\text { I would offer to help if } \\
\text { someone fell or passed } \\
\text { out in the street. }\end{array}$} & \begin{tabular}{l} 
helping professions \\
\cline { 2 - 8 }
\end{tabular} & 196 & 1,38 & 0,97 & & \\
\cline { 2 - 7 } & professions & 89 & 1,53 & 0,98 & & \\
\hline
\end{tabular}

Data in Table 6 show that there is a significant difference between career choice and altruism.

Respondents who chose a helping profession express more altruism than those respondents who chose a non-helping profession, which is indicated by high values of $\mathrm{F}$ test for the following items: Even in the most difficult times, people have the strength to be kind and generous $(F=11,77 ; p=0,001)$; It always angers me to see the powerful ignoring the powerless ( $F=11,08 ; p=0,001) ;$ It is honorable and respectable to make sacrifices for others $(F=14,02 ; p=0,000)$; The most important thing children should learn at school is being ready to help others $(F=15,06 ; p=0,000)$; I help both those who expect it and those who do not $(F=16,31 ; p=0,000)$; People are good and they should be helped $(F=12,12 ; p=0,001)$.

High $F$ value occurs in the non-helping professions as well, in particular for the following items: I believe that people should charge for their favours $(F=12,12 ; p=0,001)$; I believe that people today don't deserve any help $(F=10,79 ; p=0,001)$; People help others mostly for personal gain $(F=14,15 ; p=0,000)$; I am fed up with stories about other people's problems $(F=11,51 ; p=0,001)$.

For other items $\mathrm{F}$ value does not indicate any differences between career choice and altruism. However, by applying arithmetic mean analysis we found that pupils and students who chose helping professions display more altruism.

By applying the Pearson's chi-square test, we found two statements where there is a significant difference between respondents from helping and non-helping professions. The statement $I$ help both those who expect it and those who do not has the chi square value of $\chi 2=23,363$ at the significance level of $p=0,001$, which indicates a difference in response. This was the least frequent choice of respondents from helping professions. Namely, $1,02 \%$ of them claimed that they disagree with this statement, as opposed to $10,11 \%$ respondents from the non-helping professions. The statement It's better to save your hide than risk your neck for someone has the chi square value of $\chi^{2}=25,451$ at the significance level of $p=0,001$, which indicates a difference in response. This was the most frequent choice of the respondents from non-helping professions. Namely, 20, $22 \%$ of them said that they completely agree with this statement, as opposed to $5,61 \%$ of respondents from the helping professions. 


\section{CONCLUSION}

Our research findings reveal a significant statistical connection between the dimension of altruism and a helping profession choice. This is in line with other research results, such as Raboteg-Šarić (1997), Dimitrijević, Hanak and Milojević (2011), Grgić, Babić Čikeš and Ručević (2014), Jovanović-Srzentić, Rodić and Knežević (2015) and Nesje (2015). We found that there are statistically significant differences in the expression of altruism among pupils and students who chose helping professions (medical and educational) as opposed to respondents who did not chose these professions (Table 6).

For eight items there is a significant statistical difference in the expression of altruism in favour of helping professions. Therefore, we assume that the more pronounced altruism among respondents from helping professions results from the fact that, prior to enrollment, the respondents were aware of the fact that their future professions often involve making sacrifices for other people.

Our findings indicate that there is a need for extended research which would include other variables, such as sex, grade, success at school, success at studies. However, the findings are reassuring as it is impossible to provide help to others without possessing altruistic motives. Future preschool teachers and nurses cannot perform their works routinely, as dealing with preschool children and ill people in particular requires compassion.

The following dimensions It always angers me to see the powerful ignoring the powerless $(F=11,08 ; p=0,001)$; It is honorable and respectable to make sacrifices for others ( $F=14,02 ; p=0,000)$; The most important thing children should learn at school is being ready to help others ( $F=15,06 ; p=0,000)$; I help both those who expect it and those who do not ( $F=16,31 ; p=0,000)$; People are good and they should be helped ( $F=12,12$; $p=0,001)$; Helping others simply doesn't pay off ( $F=10,79 ; p=0,001)$; I feel sorry for people in need $(F=14,15 ; p=0,000)$ demonstrate that altruism is more pronounced in respondents who chose helping professions.

Pupils and students, future helpers, should be provided with instruction on how to communicate with people, understand their needs and feelings, react to their feelings and requests, deal with emotions piled up after a day's work with people suffering from an illness or children who are often unable to express their needs. Practical training would not only benefit children and patients, but helpers as well, especially in terms of their effectiveness at work, satisfaction at work and, finally personal welfare. Skilled empathy could become one of the most important social competences in the process of helping. Similarly, unskilled empathy could prove counterproductive for the person offering help.

These findings provide guidelines for the curriculum design so as to stimulate and develop social competences of the future helpers. Students enrolling into "helping" schools and colleges should be trained to work through a system of practical activities and supervision (Dimitrijević, Hanak, Milojević, 2011, p. 111). At the same time, altruistic behavior should be kept under control as excessive sacrifice for other people can lead to pathological altruism. 


\section{REFERENCES}

1. Batson, C. D., Powell, A. A. (2003). Altruism and Prosocial Behavior: Handbook of Psychology. Three: 19:463-484. DOI: 10.1002/0471264385.wei0519

2. Beck, R. C. (2003). Motivacija - Teorija i načela. Jastrebarsko: Naklada Slap.

3. Bramstedt, K.A. (2012). Book Review: Pathological Altruism. Barbara Oakley, Ariel Knafo, Guruprasad Madhavan, and David Sloan Wilson (editors), 2012, Oxford University Press (New York, 978-0-19-973857-1, 465 pp.) DOI 10.1007/s11673-0129362-2

4. Cialdini, R. B., Schaller M., Houlihan, D., Aips, K., Fultz, J. (1987). Empathy-Based helping: Is It Selflessly or Selfishly Motivated? Journal of Personality and Social Psychology, 52(4): 749-758.

5. Dimitrijević, A., Hanak, N., Milojević, S. (2011). Psihološke karakteristike budućih pomagača: empatičnost i vezanost studenata psihologije. Psihologija, 44(2): 97-115.

6. Dušanić, S. (2006). Religioznost i altruizam tokom i posle božićnih praznika. Godišnjak za psihologiju, 4(4-5): 223-236.

7. Eisenberg, N., Miller, P. A. (1987). The Relation of Empathy to Prosocial and Related Behaviors. Psychological Bulletin, 101(1): 91-119.

8. Fabes, R. A., Fultz, J., Eisenberg, N., May-Plumlee, T., Christopher, F. S. (1989). Effects of rewards on children's prosocial motivation: A socialization study. Developmental Psychology, 25(4): 509-515. doi:10.1037/0012-1649.25.4.509

9. Grgić, N., Babić Čikeš, A., Ručević,S (2014). Emocionalna inteligencija, agresivno i prosocijalno ponašanje učenika rane adolescentske dobi. Život i škola, 32(2): 43-60.

10. Hojat, M., Mangione, S., Nasca, T.J., Rattner, S., Erdmann, J.B., Gonnella, J.S., Magee, M. (2004). An empirical study of decline in empathy in medical school. Medical Education, 38(9): 934-941.

11. Ivanović, O. (2010). Mogućnosti podsticanja prosocijalnog ponašanja kod dece osnovnoškolskog uzrasta pomoću posebnih programa vaspitnog rada. Religija i tolerancija, 8 (14): 289-304.

12. Jukić, R. (2013). Moralne vrijednosti kao osnova odgoja. Nova prisutnost, 11(3): 401-417.

13. Joksimović S. D. (1999). Razvoj i podsticanje altruizma mladih. Nastava i vaspitanje, 48(5): 605-616.

14. Jovanović-Srzentić S., Rodić I., Knežević M. (2015). Razvoj programa promocije dobrovoljnog davanja krvi u studenstkoj populaciji Univerziteta u Beogradu. Vojnosanitetski pregled,72(6): 489-494.

15. Kišak, N., Gverić, D., Doležal, Lj., Mikšaj-Todorović, Lj., Habazin, I. (2015). Zadovoljstvo poslom pomagačkih profesija u bolničkom i zatvorskom sustavu. Kriminologija i socijalna integracija, 23(1): 1-15.

16. Krebs, D. L. (1970) Altruism: An examination of the concept and a review of the literature. Psychological Bulletin, 73(4): 258-302. http://dx.doi.org/10.1037/h0028987

17. Kruger, D. J. (2003). Evolution and altruism Combining psychological mediators with naturally selected tendencies. Evolution and Human Behavior, 24(2): 118-125. https:// 
www.researchgate.net/profile/Daniel_Kruger/publication/228792130_Evolution_ and_altruism_Combining_psychological_mediators_with_naturally_selected_tendencies/links/02e7e51dd93e4cd5da000000.pdf doi:10.1016/S1090-5138(02)00156-3

18. Luković, S., Čizmić, S. (2012). Povezanost preferencija životnih stilova i profesionalnih interesovanja petnaestogodišnjaka. Primenjena psihologija, (1): 81-108.

19. Nesje K. (2015). Nursing students' prosocial motivation: does it predict professional commitment and involvement in the job?. Journal of Advanced Nursing, 71(1): 115-125. doi: 10.1111/jan.12456

20. Međedović, J., Petrović, B., Dinić, B. (2011). Evoluciona psihologija kao teorijski okvir objašnjenja polnih razlika u altruizmu. U: J.Todorović, G.Đigić (Ur.) Knjiga rezimea VII konferencije sa međunarodnim učešćem Dani primenjene psihologije: „Psihologija komunikacije“. (37). Niš: Filozofski fakultet.

21. Milenković, S. i Šakotić-Kurbalija, J.M. (1997). Kako psihoterapeuti shvataju altruizam. Psihijatrija danas, 29(3-4): 351-384.

22. Mladenović, U., Kosanović, B. (2000). Altruizam kod studenata Novosadskog univerziteta meren skalom NSA-2000. Norma, 7(1-2): 175-192

23. Post, S.G. (2005). Altruism, Happiness, and Health: It's Good to Be Good. International Journal of Behavioral Medicine, 12(2): 66-77.

24. Raboteg-Šarić, Z. (1997). Uloga empatije i moralnog rasuđivanja u prosocijalnom ponašanju adolescenata. Društvena istraživanja, 6(4-5): 493-512.

25. Ricijaš, N., Hujić, A., Branica, V. (2006). Zadovoljstvo studijem i samoprocjena kompetentnosti studenata nekih pomagačkih profesija. Hrvatska revija za rehabilitacijska istraživanja, 42(2): 51-68.

26. Rot, N. (1994). Osnovi Socijalne psihologije. Beograd: Zavod za udžbenike i nastavna sredstva.

27. Sadžakov, S. (2014). Egoizam i altruizam. Filozofska istraživanja, 34(3): 407-426.

28. Suzić, N. (2005). Pedagogija za XXI vijek. Banja Luka: TT-Centar.

29. Suzić, N. (2014) Kompetencije za život u 21. stoljeću i školski ciljevi učenika. Pedagogijska istraživanja, 11(1): 111-122.

30. Tešanović, J., Đurić, D., Popović, D. (2011). Altruizam i empatija zdravstvenih radnika. U: J. Todorović, G. Đigić (Ur.). Knjiga rezimea VII konferencije sa međunarodnim učešćem Dani primenjene psihologije: „Psihologija komunikacije“ . (12). Niš: Filozofski fakultet.

31. Trebješanin, Ž. (2000). Rečnik psihologije. Beograd: Stubovi kulture.

32. Šokčević, Š. (2013). Suosjećanje: put prema pravednosti? Filozofska istraživanja, 33(4): 683-698.

33. Špelić, A., Zuliani, Đ., Milošević, I. (2013). Prosocijalnost i empatija u kontekstu integracijskih razreda. Hrvatska revija za rehabilitacijska istraživanja, 49(1): 135-150.

34. Žegarac, N. (1997). Empatijski stil u jednoj pomažućoj profesiji. U: Joksimović, S., Gašić-Pavišić, S. i Miočinović, Lj. (Ur.). Vaspitanje i altruizam. Beograd: Institut zapedagoška istraživanja, 308-319.

35. Warneken, F., Tomasello, M. (2009) The roots of human altruism. British Journal of Psychology, 100: 455-471. https://www.researchgate.net/profile/Felix_Warneken/ 
publication /23639211_The_roots_of_human_altruism/links/00b4951dae22d7f9cb000000.pdf DOI:10.1348/000712608X379061

36. Yagmurlu, B. (2014). Relations Among Sociocognitive Abilities and Prosocial Behavior Journal of Child and Family Studies, 23: 591-603. DOI 10.1007/s10826-013-9726-1. 